\title{
HUBUNGAN PARTUS LAMA, ANEMIA DAN HIDRAMNION DENGAN KEJADIAN ATONIA UTERI DI RUMAH SAKIT RIVAI ABDULLAH PALEMBANG TAHUN 2017
}

\author{
Putu Lusita Nati Indriani \\ Rahmi Dintia Khoirunisa \\ Universitas Kader Bangsa Palembang
}

\begin{abstract}
A B S T R A K
Atonia uteri adalah uteri tidak berkontraksi dalam 15 detik setelah dilakukan pemijatan fundus uteri (plasenta telah lahir). Tujuan penelitian ini adalah untuk mengetahui hubungan partus lama, anemia dan hidramnion dengan kejadian atonia uteri di Rumah Sakit Rivai Abdullah Palembang tahun 2017. Penelitian ini menggunakan jenis metode penelitian survey analitik dengan pendekatan Cross Sectional yaitu suatu penelitian untuk mempelajari dinamika korelasi antara faktor-faktor resiko dengan efek, dengan cara pendekatan, observasi atau pengumpulan data sekaligus pada suatu saat (point time approach). Data dalam penelitian ini adalah data sekunder dengan instrumen lembar checklist sehingga didapatkan jumlah sebanyak 91 responden. Hasil penelitian dari analisis univariat didapatkan responden yang mengalami Atonia Uteri 29 orang $(31,9 \%)$ dan yang tidak mengalami Atonia Uteri 62 orang $(68,1 \%)$. Responden yang mengalami Partus Lama sebanyak 20 orang $(22,0 \%)$ sedangkan yang tidak mengalami Partus Lama sebanyak 71 orang $(78,0 \%)$. Responden yang mengalami Anemia sebanyak 25 orang $(27,5 \%)$ sedangkan yang tidak mengalami Anemia sebanyak 66 orang $(72,5 \%)$ Responden yang mengalami Hidramnion sebanyak 18 orang $(19,8 \%)$ sedangkan yang tidak mengalami Hidramnion sebanyak 73 orang $(80,2 \%)$. Berdasarkan hasil analisis bivariat dengan menggunakan uji Chisquare didapatkan ada hubungan partus lama, anemia dan hidramnion dengan kejadian atonia uteri. Pada variabel partus lama $(\rho$ value $=0,000)$, anemia $(\rho$ value $=0,005)$, dan hidramnion $(\rho$ value $=0,034)$. Diharapkan agar Direktur Rumah Sakit Rivai Abdullah Palembang khususnya kepada bidan untuk meningkatkan pelayanan masyarakat terutama pada ibu bersalin dengan atonia uteri dalam rangka menurunkan angka kematian ibu (AKI).
\end{abstract}

Kata Kunci : Atonia Uteri, Partus Lama, Anemia, Hidramnion

\section{ABSTRACT}

The uterine atony refers the absence of contraction of the uterus in 15 seconds after, massaging the uterine hindus (the placenta was born). This study aimed to find out the relationship among prolonged parturition, anemia, and hyndramnios and the genesis of uterine antony at Rivai Abdullah Hospital of Palembang in 2017. This study used analytical survey research method with a cross sectional approach, namely research to study the correlation dynamics between risk factors and effects by means of approach, observation or data collection at the same time (point time approach). The data used in this study were the secondary data with the checklist instrument to obtain 91 respondents. The results of univariate analysis showed that respondents who suffered uterine antony were 29 people (31.9\%) and those who did not suffer from it were 62 people $(68.1 \%)$. There were 20 people (22\%) suffering from prolonged partutition, while 71 . people $(78 \%)$ did not have it. Twenty-five respondents (27.5\%) suffered from anemia and 66 people $(72.5 \%)$ did not suffer from it. There were 18 people (19.8\%) suffering from hydramnios and 73 people $(80.2 \%)$ did not suffer from it. The results of bivariate analysis using the chi-square test showed that there was a relationship among prolonged parturition, anemia, and hyndramnios and the genesis of uterine antony. Parturition variable had a $p$ value of 0.000, anemia 
variable had a $p$ value of 0.005 , and hyndramnios variable had a $p$ value of 0.034)'. It is expected that the Director of Rivai Abdullali Flospital of Palembang, especially the midwives, would improve their community services, especially maternity mothers suffering from uterine antony in order to reduce the maternal mortality rate (MMR).

Keywords: Uterine Antony, Prolonged Parturition, Anemia, Hydramnios

\section{PENDAHULUAN}

Persalinan adalah proses pengeluaran hasil konsepsi (janin dan plasenta) yang telah cukup bulan atau dapat hidup di luar kandungan melalui jalan lahir atau melalui jalan lain, dengan bantuan atau tanpa bantuan (kekuatan sendiri) (Manuaba,dkk, 2014).

Atonia uteri adalah suatu kondisi kegagalan uterus dalam berkontraksi dengan baik setelah persalinan, didefinisikan juga sebagai tidak adanya kontraksi uterus segera setelah plasenta lahir (Sukarni,dkk, 2014).

Atonia uteri adalah uteri tidak berkontraksi dalam 15 detik setelah dilakukan pemijatan fundus uteri (plasenta telah lahir) (Rukiyah,dkk, 2017).

Kematian ibu adalah kematian seorang wanita terjadi saat hamil, bersalin atau 42 hari setelah persalinan dengan penyebab yang berhubungan langsung atau tidak langsung terhadap persalinan. Data WHO menunjukan sekitar 830 orang wanita di dunia meninggal setiap harinya dikarenakan komplikasi selama kehamilan hingga persalinan. Di tahun 2015 tercatat sebanyak 303.000 ibu meninggal selama masa kehamilan hingga persalinan (WHO, 2015).

Kementerian Kesehatan Republik Indonesia menilai angka kematian ibu melahirkan di Indonesia relatif tinggi. Berdasarkan hasil Survey Demografi Kesehatan Indonesia (SDKI) menunjukkan bahwa secara nasional Angka Kematian Ibu pada tahun 2012 di Indonesia adalah 359/100.000 kelahiran hidup. Rata-rata kematian ini jauh melonjak dibanding hasil SDKI 2007 yang mencapai 228/100.000 kelahiran hidup (Satriyandari,et.al, 2017).

Menurut Profil Kesehatan Indonesia tahun 2014 empat penyebab kematian ibu terbesar yaitu perdarahan 30,3\%, hipertensi dalam kehamilan (HDK) $27,1 \%$, infeksi 7,3\%, dan lain- lain yaitu penyebab kematian ibu tidak langsung seperti kondisi penyakit kanker, ginjal, jantung atau penyakit lain yang diderita ibu sebesar 35,3\% (Satriyandari,et.al, 2017).

Target SDGs, tahun 2030 terjadi penurunan resiko Angka Kematian Ibu (AKI) yang kurang dari 70 per 100.000 kelahiran ibu dan untuk Angka Kematian pada Bayi (AKB) target SDGs tahun
2030, mengakhiri dan mencegah kematian bayi dan balita, (Kemenkes RI, 2015).

Jumlah AKI di Provinsi Sumatera Selatan pada tahun 2014 sebanyak 155 per $100.000 \mathrm{KH}$. Data tersebut mengalami peningkatan bila dibandingkan dengan tahun 2013, yaitu 146 per $100.000 \mathrm{KH}$. Jumlah kematian ibu yang masih tinggi karena deteksi dini faktor resiko oleh tenaga kesehatan kurang cermat, penanganan persalinan yang kurang adekuat / tidak sesuai prosedur serta sistem rujukan tidak sesuai dengan prosedur jejaring manual rujukan (Profil Dinas Kesehatan Provinsi Sumatera Selatan, 2015).

Jumlah AKI di Kota Palembang berdasarkan Profil Kesehatan Sumatera Selatan tahun 2013 sebanyak 13 orang dari $29.911 \mathrm{KH}$. Sementara pada tahun 2014, jumlah AKI mengalami penurunan sebanyak 12 orang dari $29.235 \mathrm{KH}$. Penyebabnya adalah perdarahan, diikuti oleh emboli paru, suspect syok kardiogenik, suspect TB, hipertensi dalam kehamilan, dan lainnya (Profil Dinas Kesehatan Kota Palembang, 2015).

Berdasarkan data yang diperoleh dari Medical Record di Instalasi Kebidanan Rumah Sakit Rivai Abdullah Palembang pada tahun 2015-2017 data Atonia Uteri didapatkan pada tahun 2015 ibu bersalin yang mengalami atonia uteri berjumlah 50 orang atau 5,9\% dari 850 ibu bersalin, tahun 2016 ibu bersalin yang mengalami atonia uteri berjumlah 125 orang atau $12,9 \%$ dari 966 ibu bersalin, tahun 2017 ibu bersalin yang mengalami atonia uteri berjumlah 193 orang atau 17,9\% dari $1.082 \mathrm{ibu}$ bersalin (Rekam Medic Rumah Sakit Rivai Abdullah Palembang Tahun 2017).

Berdasarkan penelitian Rohmawati,et.al tahun 2011 yang mengatakan bahwa ada hubungan antara partus lama dengan atonia uteri, dapat dilihat dari hasil yang ditunjukan dengan nilai $\mathrm{X}^{2}=10,280$ dan $\mathrm{p}=0,003(\mathrm{p}<0.05)$. Sedangkan nilai $\mathrm{OR}=5,333$, artinya bahwa ibu yang mengalami persalinan lama mempunyai risiko 5,333 kali lipat mengalami atonia uteri. Begitu juga dengan penelitian Ien,et.al tahun 2017 mengatakan bahwa ada hubungan antara anemia dengan atonia uteri, dapat dilihat dari hasil analisis dengan uji chi square yang diperoleh $p$ value $=0,001$. Dari hasil analisis diperoleh nilai $\mathrm{OR}=6,234$ artinya ibu yang menderita anemia (kadar hemoglobin $<11$ gr/dl) 
Jurnal Kebidanan : Jurnal Medical Science Ilmu Kesehatan Akademi Kebidanan Budi Mulia Palembang Volume.8 No.2, Desember 2018

memiliki risiko 6,234 kali mengalami kematian dibandingkan ibu yang tidak menderita anemia (kadar hemoglobin > $11 \mathrm{gr} / \mathrm{dl}$ ).

Faktor-faktor yang menyebabkan atonia uteri adalah partus lama, trauma persalinan seperti rupture uteri, keadaan umum lemah (anemia), grandemultipara, jarak hamil $<2$ tahun, umur yang terlalu muda atau terlalu tua, dan distensi rahim berlebihan (hidramnion, hamil kembar) (Manuaba, 2014).

Berdasarkan data di atas maka penulis tertarik untuk melakukan penelitian tentang "Hubungan Partus Lama, Anemia dan Hidramnion dengan Kejadian Atonia Uteri di Rumah Sakit Rivai Abdullah Palembang Tahun 2017".

\section{METODE PENELITIAN}

Jenis penelitian yang digunakan dalam penelitian ini adalah survey analitik atau penelitian yang mencoba menggali bagaimana dan mengapa fenomena kesehatan itu terjadi. Kemudian melakukan analisis dinamika korelasi antara fenomena atau antara faktor resiko dengan faktor efek. Desain peneilitian ini menggunakan Cross Sectional yaitu suatu penelitian untuk mempelajari dinamika korelasi antara faktor-faktor resiko dengan efek, dengan cara pendekatan, observasi atau pengumpulan data sekaligus pada suatu saat (point time approach) (Notoatmodjo, 2010).

Populasi adalah keseluruhan objek penelitian atau objek yang diteliti (Notoatmodjo, 2010)

Dalam penelitian ini yang digunakan sebagai populasi adalah seluruh ibu bersalin di Rumah Sakit Rivai Abdullah Palembang yang diperkirakan berjumlah 1.082 orang.

Analisa univariat bertujuan untuk menjelaskan atau mendeskripsikan karakteristik setiap variable penelitian. Pada umumnya dalam analisa ini hanya menghasilkan distribusi dan presentase dari tiap variabel (Notoatmodjo, 2010).

Analisis Bivariat adalah analisa data yang dilakukan terhadap dua variabel yang diduga berhubungan atau berkorelasi (Notoatmodjo, 2010). Uji statistik yang digunakan adalah Chi-Square, karena baik variabel independen maupun variabel dependen merupakan variabel kategorik.

\section{HASIL PENELITIAN}

\section{Pelaksanaan Penelitian}

Pengumpulan data dalam penelitian ini menggunakan data sekunder, yaitu data yang diperoleh dari orang/lain tempat lain dan bukan dilakukan oleh peneliti sendiri. Data sekunder dalam penelitian diperoleh dari catatan rekam medic di Rumah Sakit Rivai Abdullah Palembang.

\section{Penyajian Data}

\section{a. Analisa Univariat}

Analisis ini dilakukan untuk mengetahui distribusi frekuensi dan persentase dari variabel dependen (atonia uteri) dan variabel independen (partus lama, anemia, dan hidramnion) dengan 91 sampel.

\section{Atonia Uteri}

Penelitian ini dilakukan pada 91 responden, variabel atonia uteri dibagi menjadi 2 kategori yaitu "ya" (jika uterus tidak berkontraksi dalam 15 detik) dan "tidak" (jika uterus berkontraksi dalam 15 detik). Untuk lebih jelasnya dapat dilihat pada tabel 1 di bawah ini:

\section{Tabel 1 Distribusi Frekuensi Responden Berdasarkan Kejadian Atonia Uteri di Rumah Sakit Rivai Abdullah Palembang Tahun 2017}

\begin{tabular}{cccc}
\hline No & Atonia Uteri & $\begin{array}{c}\text { Frekuensi } \\
(\mathbf{N})\end{array}$ & $\begin{array}{c}\text { Persentase } \\
(\mathbf{\%})\end{array}$ \\
\hline 1 & Ya & 29 & 31,9 \\
\hline 2 & Tidak & 62 & 68,1 \\
\hline Jumlah & $\mathbf{9 1}$ & $\mathbf{1 0 0}$ \\
\hline
\end{tabular}

Berdasarkan tabel 1 diatas diketahui bahwa dari 91 responden yang mengalami atonia uteri sebanyak 29 responden $(31,9 \%)$ lebih sedikit dari responden yang tidak mengalami atonia uteri sebanyak 62 responden $(68,1 \%)$.

\section{Partus Lama}

Penelitian ini dilakukan pada 91 responden, variabel partus lama dibagi menjadi 2 kategori yaitu "ya" (jika persalinan $\geq 24$ jam pada primipara dan persalinan $\geq 18$ jam pada multipara), "tidak" (jika persalinan $<24$ jam pada primipara dan persalinan $<18$ jam pada multipara). Untuk lebih jelasnya dapat dilihat pada tabel 2 di bawah ini:

Tabel 2 Distribusi Frekuensi Responden Berdasarkan Kejadian Partus Lama di Rumah Sakit Rivai Abdullah Palembang Tahun 2017 
Jurnal Kebidanan : Jurnal Medical Science Ilmu Kesehatan Akademi Kebidanan Budi Mulia Palembang Volume.8 No.2, Desember 2018

\begin{tabular}{cccc}
\hline No & Partus Lama & $\begin{array}{c}\text { Frekuensi } \\
(\mathbf{N})\end{array}$ & $\begin{array}{c}\text { Persentase } \\
(\mathbf{\%})\end{array}$ \\
\hline 1 & Ya & 20 & 22,0 \\
\hline 2 & Tidak & 71 & 78,0 \\
\hline Jumlah & $\mathbf{9 1}$ & $\mathbf{9 1}$ \\
\hline \multicolumn{2}{c}{ Berdasarkan } & tabel 2 diatas & diketahui
\end{tabular}

bahwa dari 91 responden yang mengalami partus lama sebanyak 20 responden $(22,0 \%)$ lebih sedikit dari responden yang tidak mengalami partus lama sebanyak 71 responden $(78,0 \%)$.

\section{Anemia}

Penelitian ini dilakukan pada 91 responden, variabel anemia dibagi menjadi 2 kategori yaitu "ya" (jika $\mathrm{Hb}$ ibu $<11$ gr\%), "tidak" (jika $\mathrm{Hb}$ ibu $\geq 11$ gr\%). Untuk lebih jelasnya dapat dilihat pada tabel 3 di bawah ini:

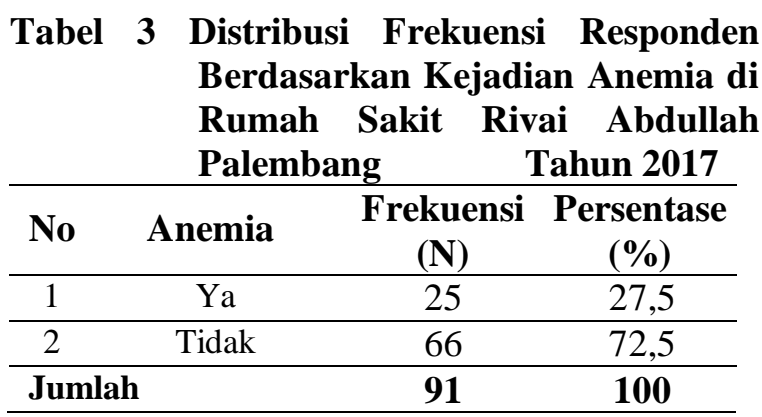

Berdasarkan tabel 3 diatas diketahui bahwa dari 91 responden yang mengalami anemia sebanyak 25 responden $(27,5 \%)$ lebih sedikit dari responden yang tidak mengalami anemia sebanyak 66 responden $(72,5 \%)$.

\section{Hidramnion}

Penelitian ini dilakukan pada 91 responden, variabel hidramnion dibagi menjadi 2 kategori yaitu "hidramnion" (jika jumlah air ketuban $>2$ liter), "tidak hidramnion" (jika jumlah air ketuban $\leq 2$ liter). Untuk lebih jelasnya dapat dilihat pada tabel 4 di bawah ini:

Tabel 4 Distribusi Frekuensi Responden Berdasarkan Kejadian Hidramnion di Rumah Sakit Rivai Abdullah Palembang Tahun 2017

\begin{tabular}{cccc}
\hline No & Hidramnion & $\begin{array}{c}\text { Frekuensi } \\
(\mathbf{N})\end{array}$ & $\begin{array}{c}\text { Persentase } \\
(\mathbf{\%})\end{array}$ \\
\hline 1 & Hidramnion & 18 & 19,8 \\
\hline 2 & $\begin{array}{c}\text { Tidak } \\
\text { Hidramnion }\end{array}$ & 73 & 80,2 \\
\hline Jumlah & $\mathbf{9 1}$ & $\mathbf{1 0 0}$ \\
\hline
\end{tabular}

Berdasarkan tabel 4 diatas diketahui bahwa dari 91 responden yang mengalami hidramnion sebanyak 18 responden $(19,8 \%)$ lebih sedikit dari responden yang tidak mengalami hidramnion sebanyak 73 responden $(80,2 \%)$.

\section{b. Analisa Bivariat}

Analisis Bivariat adalah analisa yang digunakan untuk mengetahui keterkaitan antara 2 variabel. Analisa ini dilakukan untuk mengetahui hubungan antara variabel independen (partus lama, anemia dan hidramnion) dengan variabel dependen (atonia uteri) dengan menggunakan uji Chi-square. Penelitian ini melihat hubungan variabel independen dan variabel dependen dengan komputerisasi dimana nilai $\alpha$ ditetapkan sebesar 0.05. jika nilai $\rho$ value $<0,05$ berarti ada hubungan yang bermakna antara variabel independen dan variabel dependen dan jika nilai $\rho$ value $>0,05$ berarti tidak ada hubungan yang bermakna antara variabel independen dan variabel dependen.

\section{Hubungan Partus Lama dengan Kejadian Atonia Uteri \\ Pada penelitian ini hubungan partus lama} dengan kejadian atonia uterri dikelompokkan menjadi 2 kategori yaitu "ya" (jika persalinan $\geq$ 24 jam pada primipara dan persalinan $\geq 18$ jam pada multipara), "tidak" (jika persalinan $<24$ jam pada primipara dan persalinan $<18$ jam pada multipara), untuk lebih jelasnya dapat dilihat pada tabel 5 .

Tabel 5 Distribusi Hubungan Partus Lama dengan Kejadian Atonia Uteri di Rumah Sakit Rivai Abdulah Palembang Tahun 2017

\begin{tabular}{|c|c|c|c|c|c|c|c|c|c|}
\hline \multirow{3}{*}{ No } & \multirow{3}{*}{$\begin{array}{l}\text { Partus } \\
\text { Lama }\end{array}$} & \multicolumn{4}{|c|}{ Atonia Uteri } & \multirow{2}{*}{\multicolumn{2}{|c|}{ Jumlah }} & \multirow{3}{*}{$\begin{array}{c}\mathbf{P} \\
\text { Value }\end{array}$} & \multirow{3}{*}{ OR } \\
\hline & & \multicolumn{2}{|c|}{ Ya } & \multicolumn{2}{|c|}{ Tidak } & & & & \\
\hline & & $\mathbf{n}$ & $\%$ & $\mathbf{n}$ & $\%$ & $\mathbf{N}$ & $\%$ & & \\
\hline 1. & $\mathrm{Ya}$ & 16 & 80,0 & 4 & 20,0 & 20 & 100 & \multirow{3}{*}{0,000} & \multirow{3}{*}{17,846} \\
\hline 2. & Tidak & 13 & 18,3 & 58 & 81,7 & 71 & 100 & & \\
\hline & nlah & 29 & - & 62 & - & 91 & 100 & & \\
\hline
\end{tabular}

Berdasarkan tabel 5, diketahui bahwa dari 20 responden dengan partus lama ada 16 orang (80\%) yang mengalami atonia uteri dan 4 orang (20\%) yang tidak mengalami atonia uteri sedangkan dari 71 responden yang tidak mengalami partus lama ada 13 orang $(18,3 \%)$ yang mengalami atonia uteri dan 58 orang $(81,7 \%)$ yang tidak mengalami atonia uteri. 
Berdasarkan hasil uji Chi-Square didapatkan $\rho$ value $=0,000<\alpha(0,05)$, berarti ada hubungan yang bermakna antara partus lama dengan kejadian atonia uteri. Sehingga hipotesis yang menyatakan ada hubungan yang bermakna antara partus lama dengan kejadian atonia uteri terbukti secara statistik.

Berdasarkan hasil uji statistik didapatkan juga nilai OR sebesar 17,846 artinya responden yang mengalami partus lama memiliki peluang 17,8 kali lebih besar mengalami atonia uteri dibandingkan responden yang tidak mengalami partus lama.

\section{Hubungan Anemia dengan Kejadian Atonia Uteri}

Pada penelitian ini hubungan anemia dengan kejadian atonia uteri dikelompokkan menjadi 2 kategori yaitu "ya" (jika $\mathrm{Hb}$ ibu $<11$ gr\%), "tidak" (jika Hb ibu $\geq 11$ gr\%), untuk lebih jelasnya dapat dilihat pada tabel 6 .

Tabel 6 Distribusi Hubungan Anemia dengan Kejadian Atonia Uteri di Rumah Sakit Rivai Abdulah Palembang Tahun 2017

\begin{tabular}{cccccccccc}
\hline & & \multicolumn{4}{c}{ Atonia Uteri } & \multirow{2}{*}{ Jumlah } & \multirow{2}{*}{$\mathbf{P}$} \\
\cline { 3 - 7 } No & Anemia & \multicolumn{2}{c}{ Ya } & \multicolumn{3}{c}{ Tidak } & & \\
\cline { 3 - 7 } & & $\mathbf{n}$ & $\mathbf{\%}$ & $\mathbf{n}$ & $\mathbf{\%}$ & $\mathbf{N}$ & $\mathbf{\%}$ & & \\
\hline 1 & Ya & 14 & 56,0 & 11 & 44,0 & 25 & 100 & & \\
2 & Tidak & 15 & 22,7 & 51 & 77,3 & 66 & 100 & 0,005 & 4,327 \\
\hline & Jumlah & $\mathbf{2 9}$ & - & $\mathbf{6 2}$ & - & $\mathbf{9 1}$ & $\mathbf{1 0 0}$ & & \\
\hline
\end{tabular}

Berdasarkan tabel 6, diketahui bahwa dari 25 responden dengan anemia ada 14 orang $(56 \%)$ yang mengalami atonia uteri dan 11 orang $(44 \%)$ yang tidak mengalami atonia uteri sedangkan dari 66 responden yang tidak mengalami anemia ada 15 orang $(22,7 \%)$ yang mengalami atonia uteri dan 51 orang $(77,3 \%)$ yang tidak mengalami atonia uteri.

Berdasarkan hasil uji Chi-Square didapatkan $\rho$ value $=0,005<\alpha(0,05)$, berarti ada hubungan yang bermakna antara anemia dengan kejadian atonia uteri. Sehingga hipotesis yang menyatakan ada hubungan yang bermakna antara anemia dengan kejadian atonia uteri terbukti secara statistik.

Berdasarkan hasil uji statistik didapatkan juga nilai OR sebesar 4,327 artinya responden yang mengalami anemia memiliki peluang 4,3 kali lebih besar mengalami atonia uteri dibandingkan responden yang tidak mengalami anemia.

\section{Hubungan Hidramnion dengan Kejadian Atonia Uteri}

Pada penelitian ini hubungan hidramnion dengan kejadian atonia uteri dikelompokkan menjadi 2 kategori yaitu "hidramnion" (jika jumlah air ketuban $>2$ liter), "tidak hidramnion" (jika jumlah air ketuban $\leq 2$ liter), untuk lebih jelasnya dapat dilihat pada tabel 7 .

Tabel 7 Distribusi Hubungan Hidramnion dengan Kejadian Atonia Uteri di Rumah Sakit Rivai Abdulah Palembang Tahun 2017

\begin{tabular}{|c|c|c|c|c|c|c|c|c|c|}
\hline \multirow{3}{*}{ No } & \multirow{3}{*}{ Hidramnion } & \multicolumn{4}{|c|}{ Atonia Uteri } & \multirow{2}{*}{\multicolumn{2}{|c|}{ Jumlah }} & \multirow{3}{*}{\multicolumn{2}{|c|}{$\begin{array}{c}\mathbf{P} \\
\text { Value }\end{array}$}} \\
\hline & & \multicolumn{2}{|c|}{ Ya } & \multicolumn{2}{|c|}{ Tidak } & & & & \\
\hline & & $\mathbf{n}$ & $\%$ & $\mathbf{n}$ & $\%$ & $\mathbf{N}$ & $\%$ & & \\
\hline \multirow{3}{*}{$\begin{array}{l}1 \\
2\end{array}$} & Hidramnion & 10 & 55 & 8 & 44,4 & 18 & 100 & \multirow{2}{*}{\multicolumn{2}{|c|}{$0,0343,553$}} \\
\hline & $\begin{array}{l}\text { Tidak } \\
\text { Hidramnion }\end{array}$ & 19 & 26,0 & 54 & 74,0 & 73 & 100 & & \\
\hline & Jumlah & 29 & - & 62 & - & 91 & 100 & & \\
\hline
\end{tabular}

Berdasarkan tabel 7, diketahui bahwa dari 18 responden dengan hidramnion ada 10 orang $(55,6 \%)$ yang mengalami atonia uteri dan 8 orang $(44,4 \%)$ yang tidak mengalami atonia uteri sedangkan dari 73 responden yang tidak mengalami anemia ada 19 orang (26\%) yang mengalami atonia uteri dan 54 orang $(74 \%)$ yang tidak mengalami atonia uteri.

Berdasarkan hasil uji Chi-Square didapatkan $\rho$ value $=0,034<\alpha(0,05)$, berarti ada hubungan yang bermakna antara hidramnion dengan kejadian atonia uteri. Sehingga hipotesis yang menyatakan ada hubungan yang bermakna antara hidramnion dengan kejadian atonia uteri terbukti secara statistik.

Berdasarkan hasil uji statistik didapatkan juga nilai OR sebesar 3,553 artinya responden yang mengalami hidramnion memiliki peluang 3,5 kali lebih besar mengalami atonia uteri dibandingkan responden yang tidak mengalami hidramnion.

\section{PEMBAHASAN}

\section{Atonia Uteri}

Pada penelitian ini, atonia uteri dibagi menjadi 2 kategori yaitu "ya" (jika uterus tidak berkontraksi dalam 15 detik) dan "tidak" (jika uterus berkontraksi dalam 15 detik). Berdasarkan hasil penelitian didapatkan responden yang diteliti berjumlah 91 responden yang mengalami atonia uteri sebanyak 29 responden $(31,9 \%)$ lebih sedikit dibandingkan dengan responden yang tidak mengalami atonia uteri yaitu sebanyak 62 responden $(68,1 \%)$. 
Menurut Manuaba (2014), secara umum yang menjadi faktor-faktor penyebab atonia uteri adalah partus lama, anemia dan hidramnion.

\section{Hubungan Partus Lama dengan Kejadian Atonia Uteri}

Pada penelitian ini hubungan partus lama dengan kejadian atonia uteri dikelompokkan menjadi 2 kategori yaitu "ya" (jika persalinan $\geq$ 24 jam pada primipara dan persalinan $\geq 18$ jam pada multipara), "tidak" (jika persalinan $<24$ jam pada primipara dan persalinan $<18$ jam pada multipara).

Dari hasil univariat, didapatkan 91 responden berdasarkan partus lama diketahui ada 20 responden $(22,0 \%)$ yang mengalami partus lama dan yang tidak mengalami partus lama berjumlah 71 responden $(78,0 \%)$.

Dari hasil bivariat diketahui bahwa dari 20 responden ibu dengan partus lama ada 16 responden $(80,0 \%)$ yang mengalami atonia uteri dan ada 4 responden $(20,0 \%)$ yang tidak mengalami atonia uteri sedangkan 71 responden ibu dengan tidak partus lama ada 13 responden $(18,3 \%)$ yang mengalami atonia uteri dan ada 58 $(81,7 \%)$ responden yang tidak mengalami atonia uteri.

Berdasarkan hasil uji Chi-Square didapatkan nilai $\rho$ value $=0,000<\alpha=0,05$ ) yang berarti ada hubungan yang bermakna antara partus lama dengan kejadian atonia uteri di Rumah Sakit Rivai Abdullah Palembang tahun 2017 sehingga hipotesis yang menyatakan ada hubungan partus lama dengan atonia uteri terbukti secara statistik.

Berdasarkan hasil uji statistik nilai OR didapat 17,846 artinya responden yang mengalami partus lama memiliki peluang 17,8 kali lebih besar mengalami atonia uteri dibandingkan responden yang tidak mengalami partus lama.

Penelitian ini sejalan dengan penelitian Rahmawati,et.al (2016) yang mengatakan bahwa ada hubungan antara partus lama dengan atonia uteri, dapat dilihat dari hasil uji chi-square $\mathrm{p}=0,01$ maka $\mathrm{p}<\alpha(0,05)$, sehingga $\mathrm{H}_{0}$ ditolak artinya ada hubungan partus lama dengan kejadian perdarahan post partum.

Hasil penelitian ini sesuai dengan teori Rohmawati,et.al, (2011), yang menyatakan bahwa Partus lama merupakan salah satu faktor penyebab kejadian atonia uteri karena dapat mengakibatkan kelelahan uterus sehingga uterus cenderung berkontraksi lemah (atonia uteri).
Berdasarkan penelitian yang telah dilakukan, peneliti berpendapat bahwa responden dengan partus lama memiliki peluang lebih besar mengalami atonia uteri dibandingkan dengan responden yang tidak partus lama.

\section{Hubungan Anemia dengan Kejadian Atonia Uteri}

Pada penelitian ini hubungan anemia dengan kejadian atonia uteri dikelompokkan menjadi 2 kategori yaitu "ya" (jika $\mathrm{Hb}$ ibu $<11$ gr\%), "tidak" (jika $\mathrm{Hb}$ ibu $\geq 11$ gr\%).

Dari hasil univariat, didapatkan 91 responden berdasarkan anemia diketahui ada 25 responden $(27,5 \%)$ yang mengalami anemia dan yang tidak mengalami anemia berjumlah 66 responden $(72,5 \%)$.

Dari hasil bivariat diketahui bahwa dari 25 responden ibu dengan anemia ada 14 orang $(56,0 \%)$ yang mengalami atonia uteri dan ada 11 responden $(44,0 \%)$ yang tidak mengalami atonia uteri sedangkan 66 responden ibu dengan tidak anemia ada 15 responden $(22,7 \%)$ yang mengalami atonia uteri dan ada 51 (77,3\%) responden yang tidak mengalami atonia uteri.

Berdasarkan hasil uji Chi-Square didapatkan nilai $\rho$ value $=0,005<\alpha=0,05$ ) yang berarti ada hubungan yang bermakna antara anemia dengan kejadian atonia uteri di Rumah Sakit Rivai Abdullah Palembang tahun 2017 sehingga hipotesis yang menyatakan ada hubungan anemia dengan atonia uteri terbukti secara statistik.

Berdasarkan hasil uji statistik nilai OR didapat 4,327 artinya responden yang mengalami anemia memiliki peluang 4,3 kali lebih besar mengalami atonia uteri dibandingkan responden yang tidak mengalami anemia.

Penelitian ini sejalan dengan penelitian Ien,et.al tahun 2017 mengatakan bahwa ada hubungan antara anemia dengan atonia uteri, dapat dilihat dari hasil analisis dengan uji chi square yang diperoleh $p$ value $=0,001$. Dari hasil analisis diperoleh nilai $\mathrm{OR}=6,234$ artinya ibu yang menderita anemia (kadar hemoglobin $<11$ gr/dl) memiliki risiko 6,234 kali mengalami kematian dibandingkan ibu yang tidak menderita anemia (kadar hemoglobin > $11 \mathrm{gr} / \mathrm{dl}$ ).

Hasil penelitian ini sesuai dengan teori Lestari (2013), bahwa anemia berpengaruh terhadap atonia uteri dikarenakan kurangnya oksigen yang dibawa ke sel tubuh, otak, maupun ke uterus akibat kekurangan hemoglobin dalam darah. Jumlah oksigen dalam darah yang kurang menyebabkan otot-otot uterus tidak berkontraksi 
dengan adekuat sehingga timbul atonia uteri yang mengakibatkan perdarahan banyak.

Berdasarkan penelitian yang telah dilakukan, peneliti berpendapat bahwa responden dengan anemia memiliki peluang lebih besar mengalami atonia uteri dibandingkan dengan responden yang tidak anemia.

\section{Hubungan Hidramnion dengan Kejadian Atonia Uteri}

Pada penelitian ini hubungan hidramnion dengan kejadian atonia uteri dikelompokkan menjadi 2 kategori yaitu "hidramnion" (jika jumlah air ketuban $>2$ liter), "tidak hidramnion" (jika jumlah air ketuban $\leq 2$ liter).

Dari hasil univariat, didapatkan 91responden berdasarkan hidramnion diketahui ada 18 responden $(19,8 \%)$ yang mengalami hidramnion dan yang tidak mengalami anemia berjumlah 73 responden $(80,2 \%)$.

Dari hasil bivariat diketahui bahwa dari 18 responden ibu dengan hidramnion ada 10 orang $(55,6 \%)$ yang mengalami atonia uteri dan ada 8 responden $(44,4 \%)$ yang tidak mengalami atonia uteri sedangkan 73 responden ibu dengan tidak hidramnion ada 19 responden $(26,0 \%)$ yang mengalami atonia uteri dan ada $54(74,0 \%)$ responden yang tidak mengalami atonia uteri.

Berdasarkan hasil uji Chi-Square didapatkan nilai $\rho$ value $=0,034<\alpha=0,05$ ) yang berarti ada hubungan yang bermakna antara hidramnion dengan kejadian atonia uteri di Rumah Sakit Rivai Abdullah Palembang tahun 2017 sehingga hipotesis yang menyatakan ada hubungan hidramnion dengan atonia uteri terbukti secara statistik.

Berdasarkan hasil uji statistik nilai OR didapat 3,553 artinya responden yang mengalami hidramnion memiliki peluang 3,5 kali lebih besar mengalami atonia uteri dibandingkan responden yang tidak mengalami hidramnion.

Penelitian ini tidak sejalan dengan penelitian Satriyandari,et.al tahun 2017 mengatakan bahwa tidak ada hubungan antara hidramnion dengan atonia uteri, dapat dilihat dari hasil Uji Chi-Square Test menunjukkan bahwa nilai $p$ value $=1,000>$ dari nilai $\alpha=0,05$ sehingga dapat dinyatakan bahwa tidak terdapat hubungan antara peregangan uterus berlebihan dengan perdarahan postpartum di RSUD Panembahan Senopati Bantul Tahun 2015. Hasil analisis nilai Odds Ratio $(\mathrm{OR})=0,649$, OR $<1$ sehingga dapat dinyatakan bahwa peregangan uterus berlebihan bukan merupakan faktor penyebab perdarahan postpartum. Namun, pada teori Imron,dkk tahun 2016 mengatakan penyebab atonia uteri adalah overdistensi uterus seperti polihidramnion.

Hasil penelitian ini sesuai dengan teori Satriyandari,et.al (2017), yang menyatakan bahwa hidramnion juga berpengaruh terhadap atonia uteri dikarenakan hidramnion dapat menyebabkan overdistensi uterus yang akan mengakibatkan uterus tidak mampu berkontraksi segera setelah plasenta lahir sehingga sering menyebabkan perdarahan postpartum pada ibu bersalin. Pada kondisi ini miometrium renggang dengan hebat sehingga kontraksi uterus setelah bayi lahir menjadi tidak efisien.

Berdasarkan penelitian yang telah dilakukan, peneliti berpendapat bahwa responden dengan hidramnion memiliki peluang lebih besar mengalami atonia uteri dibandingkan dengan responden yang tidak hidramnion.

\section{KESIMPULAN}

Berdasarkan hasil penelitian yang dilakukan maka dapat disimpulkan sebagai berikut:

1. Ada hubungan bermakna antara partus lama, anemia dan hidramnion secara simultan dengan kejadian atonia uteri di Rumah Sakit Rivai Abdullah Palembang Tahun 2017.

2. Ada hubungan bermakna partus lama dengan kejadian atonia uteri secara parsial di Rumah Sakit Rivai Abdullah Palembang Tahun 2017.

3. Ada hubungan bermakna anemia dengan kejadian atonia uteri secara parsial di Rumah Sakit Rivai Abdullah Palembang Tahun 2017.

4. Ada hubungan bermakna hidramnion dengan kejadian atonia uteri secara parsial di Rumah Sakit Rivai Abdullah Palembang Tahun 2017.

\section{SARAN}

1. Kepada Direktur Rumah Sakit Rivai Abdullah Palembang

Hasil penelitian ini diharapkan dapat digunakan sebagai masukan bagi petugas kesehatan khususnya di Rumah Sakit Rivai Abdullah Palembang dalam meningkatkan pelayanan masyarakat terutama pada ibu bersalin dengan atonia uteri dalam rangka menurunkan angka kematian ibu (AKI).

\section{Kepada Rektor Universitas Kader Bangsa}

Diharapkan penelitian ini dapat digunakan sebagai bahan masukan dan informasi untuk melengkapi literature kepustakaan sehingga dapat menunjang pengetahuan dan wawancara 
Jurnal Kebidanan : Jurnal Medical Science Ilmu Kesehatan Akademi Kebidanan Budi Mulia Palembang Volume.8 No.2, Desember 2018

mahasiswa serta dapat dilakukan penelitian lebih lanjut.

3. Kepada Peneliti

Dengan penelitian ini diharapkan dapat menambah wawasan dan pengetahuan untuk melaksanakan peran dan fungsi bidan sebagai bidan pendidik, pengelola, pelaksana, dan peneliti.

4. Kepada Peneliti Selanjutnya

Dengan penelitian ini diharapkan dapat dijadikan sebagai bahan acuan untuk pengembangan ilmu pengetahuan yang berhubungan dengan atonia uteri dan referensi untuk studi lanjut bagi peneliti awal untuk melakukan penelitian selanjutnya yang berkaitan dengan atonia uteri sehingga dapat dihasilkan sebuah penelitian dengan hasil yang lebih baik dan bermanfaat.

\section{DAFTAR PUSTAKA}

Dinkes Kota Palembang. 2015. Profil Kesehatan Provinsi Sumatera Selatan. Palembang: Dinas Kesehatan Kota Palembang. 2015. "Profil Kesehatan Provinsi Sumatera Selatan Tahun 2015”. 07 April 2018. http://www.depkes.go.id

Hidayat,A.Aziz Alimul.2012.Metode Penelitian Kebidanan dan Teknik Analisis Data.Jakarta:Salemba Medika.

Ien,et.al.(2017).Kejadian Kematian Maternal di RSUD DR.Soesilo Slawi.HIGEIA Journal of Public Health Research and Evelopment.Vol.IV.

Imron,Riyanti,dkk.2016.Buku Ajar Asuhan Kebidanan Patologi dalam Kehamilan, Persalinan, Nifas dan Gangguan Reproduksi.Jakarta:CV.Trans Info Media.

Kemenkes RI.2013.Buku Saku Pelayanan Kesehatan Ibu di Fasilitas Kesehatan Dasar dan Rujukan.Jakarta:Unicef.

Kementrian Kesehatan Republik Indonesia. 2015. "Profil Kesehatan Indonesia Tahun 2015". 07 April 2018. http://www.depkes.go.id

Lestari, Gangsai Indah.(2013).Analisis Hubungan Anemia dengan Perdarahan Postpartum di RSUD Jendral Ahmad Yani Kota Metro Tahun 2013.Jurnal Kesehatan Metro Sai Wawai.Vol.VII No.2. $\begin{array}{crr}\text { Lisnawati,Lilis.2013.Asuhan } & \text { Kebidanan } & \text { Terkini } \\ \text { Kegawatdaruratan } & \text { Maternal } & \text { dan } \\ \text { Neonatal.Jakarta:CV.Trans Info Medika. }\end{array}$

Manuaba,Ide Ayu C,dkk. 2014. Ilmu Kebidanan,Penyakit Kandungan,dan KB.Jakarta:EGC.

Marmi,dkk.2011. Asuhan Kebidanan Patologi. Yogyakarta: Pustaka Pelajar.

Notoatmodjo,Soekidjo. 2010. Metode Penelitian Kesehatan. Jakarta: Rineka Cipta.

Prawirohardjo,Sarwono.2014.Ilmu

Kebidanan.Jakarta:PT.Bina Pustaka.

Purwoastuti,TH.Endang,dkk.2015.Ilmu Obstetri dan Ginekologi Sosial untuk Kebidanan.Yogyakarta:PT.Pustaka Baru.

Rohmawati,et al.(2011).Hubungan Persalinan Lama dengan Kejadian Atonia Uteri di RSUD Dr. Moewardi Surakarta.Journal Involusi Kebidanan.Vol.I No.2.

Rukiyah,Ai Yeyeh,dkk.2010.Asuhan Kebidanan 4 Patologi.Jakarta:Trans Info Media.

Rukiyah,Ai Yeyeh,dkk.2017.Asuhan Kebidanan 4 Patologi.Jakarta:Trans Info Media.

Satriyandari,Yekti,et al.(2017).Faktor-Faktor yang Mempengaruhi Kejadian Perdarahan Postpartum.Journal of Health Studies. Vol.1 No.1.

Sukarni,Icesmi,dkk. 2014. Patologi Kehamilan, Persalinan, Nifas dan Neonatus Resiko Tinggi.Yogyakarta:Nuha Medika.

Sulistyawati,Ari.2012.Asuhan Kebidanan Pada Masa Kehamilan. Jakarta: Salemba Medika.

WHO Media Centre. 2015. Maternal Mortality. 07 April 2018. http://www.who.int/ mediacentre/ factsheets/fs348/en/ 
